\title{
The Italian Constitutional Court in its Context: A Narrative
}

\author{
Diletta Tega*
}

Italian Constitutional Court, development of re-centralised case law against the displacement of national constitutional courts - Italian Constitutional Court challenges the Simmenthal doctrine - Double preliminary questions - The Italian Constitutional Court's continuous need for legitimation - The Italian Constitutional Court's adaptation of its case law and doctrines to the legal and political context

\section{INTRODUCTION}

In recent years, the dichotomy of dialogue/conflict with the Court of Justice of the European Union has re-emerged in Italy in relation to a series of prominent rulings by the Italian Constitutional Court. These include, in particular, the 'Taricco saga' ${ }^{1}$ as well as judgment no. 269/2017 (followed by the further clarifications given by the Court in 2019 and 2020). ${ }^{2}$ The same is true also as regards the

*Diletta Tega is Associate Professor of Constitutional Law at the Alma Mater Studiorum University of Bologna. She has worked as a clerk at the Italian Constitutional Court (20112014). This article is the result of research carried out under the project Prin 2017 'Where is Europe going? Paths and perspectives of the European federalizing process'.

${ }^{1}$ Italian Constitutional Court, order no. 24/2017 and decision no. 115/2018; G. Piccirilli, 'The "Taricco Saga": The Italian Constitutional Court continues its European journey', 14 EuConst (2018) p. 814.

${ }^{2}$ Already discussed in detail by G. Martinico and G. Repetto, 'Fundamental Rights and Constitutional Duels in Europe: An Italian Perspective on Case 269/2017 of the Italian Constitutional Court and Its Aftermath', 15 EuConst (2019) p. 731.

European Constitutional Law Review, 17: 369-393, 2021

(C) The Author(s), 2021. Published by Cambridge University Press on behalf of European Constitutional Law Review. This is an Open Access article, distributed under the terms of the Creative Commons Attribution licence (http://creativecommons.org/licenses/by/4.0/), which permits unrestricted re-use, distribution, and reproduction in any medium, provided the original work is properly cited. doi:10.1017/S1574019621000274 
relationship with the European Court of Human Rights and in particular in relation to decision no. $49 / 2015 .^{3}$

This case law has been read in the light both of the rights revolution that has unfolded in Europe since the Charter of Fundamental Rights of the European Union (henceforth: the Charter) entered into force, as well as the displacement of constitutional courts within the EU due to ordinary courts favouring preliminary references over domestic judicial review, which has triggered a form of de-centralisation of constitutional review ${ }^{4}$ (in particular, Italian ordinary courts are second only to German courts in terms of the number of preliminary references made each year). ${ }^{5}$

This study seeks to demonstrate that the analysis of some distinguishing features developed by the Italian Constitutional Court adds further substance to the current narrative concerning the dynamics that are developing between European Court of Justice and Kelsenian European constitutional courts. I argue that a consideration of the main reasons underlying the actions of constitutional courts such as the Italian Constitutional Court can offer an interpretative context beyond the usual dichotomy between dialogue and conflict - a dichotomy which is not always satisfactory. In other words, understanding recent developments such as those concerning the relations between the Italian Constitutional Court and the European Court of Justice requires not only theories, models and analysis of the multi-layered system of rights protection, but also a certain comprehension of the specific role of the national Court within the institutional system, at a given moment. $^{6}$

The adoption of a national perspective is also useful in clarifying that the principal aim of the solutions proposed by constitutional courts is not to engage in either dialogue or conflict with the European Court of Justice, or indeed the European Court of Human Rights; it is rather to give effect to the principle of constitutional legitimacy as well as the requirement to dispense justice,

\footnotetext{
${ }^{3}$ In this decision the Italian court referred in an extremely peremptory manner to a series of situations in which the ordinary courts are not obliged to following the case law of the ECtHR. The Italian decision appears to be quite similar to that reached by the Supreme Court of the United Kingdom, $R$ (on the application of Chester) (Appellant) v Secretary of State for Justice (Respondent) and McGeoch (AP) (Appellant) $\mathrm{v}$ Lord President of the Council and Another (Respondents) (Scotland) [2013] UKSC 63, quoted by D. Lustig and J.H.H. Weiler, 'Judicial Review in the Contemporary World - Retrospective and Prospective', 16 International Journal of Constitutional Law (2018) p. 315. See D. Tega, 'The Italian Way: a Blend of Cooperation and Hubris', 77 ZaöRV The Heidelberg Journal of International Law/Zeitschrift für ausländisches öffentliches Recht und Völkerrecht (2017) p. 685.

${ }^{4} J$. Komárek, 'The Place of Constitutional Courts in the EU', 9 EuConst (2013) p. 420 at p. 421.

${ }^{5}$ Annual report Court of Justice of the European Union 2019, Judicial activity, p. 163, available at $\langle$ https://curia.europa.eu/jcms/jcms/Jo2_7000/en/〉, visited 12 August 2021.

${ }^{6}$ See Komárek, supra n. 4, p. 422.
} 
reinforcing, in the end, the role of supreme guardian of the Constitution. The first goal manifests itself both through the protection of rights granted under the Constitution (which is often more fully articulated than the protection provided for under the EU Charter and within the case law of the European Court of Justice) as well as through the fundamental rule that a declaration of unconstitutionality has effect erga omnes, expunging the unconstitutional provision from the legal system forever. The requirement to dispense justice entails:

contributing, even if on a minimal and marginal scale, to giving real effect to the Constitution as part of the legal order, extracting it from the rarefied context of 'super-primary' norms in order to bring it to life within social relations, and to ensure that it is present within agreements and the resolution of disputes, as an all-encompassing guarantee of freedom and equality within civil society and within relations between civil society and the state. ${ }^{7}$

Both ends benefit the legitimacy and reputation of constitutional courts.

Ultimately, to compare and contrast constitutional courts' national and European roles can help to cast light on the reasons for decisions that have innovated on consolidated case law and the traditional structure of relations between national law and EU law.

The Italian experience (which has been partially overlooked within the international academic debate in the past due to linguistic barriers ${ }^{8}$ ) is valuable for significant reasons: in general, it is a highly reputed Kelsenian court - with no provision for dissenting opinions ${ }^{9}$ or direct individual access ${ }^{10}-$ which has always

${ }^{7}$ G. Silvestri, 'Del rendere giustizia costituzionale' [On dispensing constitutional justice], 13 November 2020, p. 15, at /www.questionegiustizia.it/articolo/del-rendere-giustiziacostituzionale $\rangle$, visited 12 August 2021.

${ }^{8} \mathrm{~V}$. Barsotti et al., Italian Constitutional Justice in Global Context (Oxford University Press 2016); T. Groppi, "The Italian Constitutional Court: Towards a "Multilevel System" of Constitutional Review?', 23 Journal of Comparative Law (2008) p. 100; J.O. Frosini, 'Constitutional Justice', in G.F. Ferrari (ed.), Introduction to Italian Public Law (2008) p. 183; P. Pasquino, 'Constitutional Adjudication and Democracy. Comparative Perspectives: USA, France, Italy', 11 Ratio Juris (1998) p. 38. An English translation of a selection of the most important decisions of the Italian Constitutional Court is available and constantly updated on the Court's website.

${ }^{9}$ D. Tega, 'Collegiality Over Personality: The Rejection of Separate Opinions in Italy', in V. Barsotti et al. (eds.), Dialogues on Italian Constitutional Justice. A Comparative Perspective (Routledge-Giappichelli 2020) p. 107; K. Kelemen, Judicial Dissent in European Constitutional Court. A Comparative and Legal Perspective (Routledge 2018).

${ }^{10}$ E. Lamarque, 'Direct Constitutional Complaint and Italian Style do not Match. Why Is That?', in Barsotti et al., supra n. 9, p. 143; G. Gentili, 'Comparison of European systems of direct access to constitutional judges: exploring advantages for the Italian Constitutional Court', 4 Italian Journal of Public Law (2012) p. 159. 
been immune to political conditioning and, nowadays, to populist pressures. Using the tool of incidental references (ricorso in via incidentale), ${ }^{11}$ it has developed a detailed body of case law, in particular on crucial issues such as the protection of fundamental rights and the primacy of EU law. It has also benefited from genuine engagement with an extremely solid doctrinal tradition, in particular concerning the judicial review of legislation.

Moreover, it is characterised by a consistent internationalism, understood as openness towards international organisations ensuring peace and justice among nations, which is enshrined in the Constitution (Article 11) and developed as a prominent feature of constitutional case law. From this perspective, I shall argue that the Italian Constitutional Court fits perfectly into the third wave of judicial review as described by Lustig and Weiler: ${ }^{12}$ a wave arising not out of political disputes and strategies, but mostly within the context of constitutional adjudication, as it takes into account the role of international and supranational tribunals such as the European Court of Human Rights, the International Court of Justice and the European Court of Justice.

This article will focus on two key concepts, with the aim of appreciating the central significance that the Constitutional Court has acquired since 1956 (the year in which its first judgment was issued): legitimation and context. ${ }^{13}$ In particular, based on an analysis of Italy's experience, considered within its own context, it is possible to make four broad claims.

(1) The Court is currently pursuing a new quest for centrality, a so-called re-centralisation involving a redefinition of the boundaries of constitutional review, vis-à-vis political discretion and the role of the ordinary and European courts.

(2) It will not come as any surprise that, as has occurred during this recent era, the role of the Constitutional Court has changed over time, as have doctrines within constitutional case law: although the legislation governing the Court has remained largely unchanged, it is the constitutional system itself, considered broadly, ${ }^{14}$ that has undergone changes, including in particular the overall context within which the Court operates. ${ }^{15}$

\footnotetext{
${ }^{11} \mathrm{G}$. Repetto, Il canone dell'incidentalità costituzionale. Trasformazioni e continuità [Incidental references as a canon: transformations and continuity in judicial review of legislation] (Editoriale Scientifica 2017).

${ }^{12}$ Lustig and Weiler, supra n. 3.

${ }^{13}$ See D. Tega, La Corte nel contesto [The Court in context] (BUP 2020).

${ }^{14} \mathrm{~A}$. Barbera, 'Costituzione della Repubblica italiana', in VIII Enciclopedia del diritto Annali (Giuffrè 2015) p. 263.

${ }^{15}$ L. Elia, 'Intervento' [Intervention], in P. Pasquino and B. Randazzo (eds.), Come decidono le Corti Costituzionali (e altre Corti) [How constitutional (and other) courts make decisions] (Giuffrè 2009) p. 130.
} 
(3) The fundamental inspiration for Court's action, throughout all of these changes and eras, has been and still is the perennial search for legitimation, construed as prestige and authoritativeness of such a type as to give tangible force to the institution, its powers and its decisions. As argued by the renowned constitutionalist Leopoldo Elia (a politician and former President of the Italian Constitutional Court), the Court has a continuous need for re-legitimation, as do all institutions within modern democracies, and this need has to be satisfied. This quest must be brought always forward, with different strategies if need be, as the volatile context changes unceasingly; lately, this has led to re-centralisation. I shall clarify the concept of legitimation in greater detail in the conclusions.

(4) More generally, there has been a tendency towards change in constitutional standards. This is an issue that has recurred throughout the history of modern law, which strives to be an instrument of stability and predictability, whilst at the same time however being also subject to a continuous need to adapt existing rules and criteria. Luhmann has suggested a name for this apparent contradiction using the concepts of 'normative' expectations and 'cognitive' expectations, ${ }^{16}$ with the former referring to expectations that are upheld even if someone acts against them, while cognitive expectations are those that are either adapted or abandoned when disappointed. When operating at the constitutional level, this couplet can be adapted and applied to new contexts, as constitutional standards cannot disregard political considerations, which the various constitutional courts take into account to varying degrees.

\section{AN ERA OF RE-CENTRALISATION}

The case law of the Constitutional Court from the most recent era (2011-2020) has been characterised by a series of unprecedented choices concerning both substantive and procedural issues, which have resulted in new departures from consolidated lines of case law. I define this as a judicial era of re-centralisation, as the Court aims at reasserting its own central position in the system by reclaiming operative spaces previously relinquished to other institutional actors. This will be a recurring theme in this essay, but it is useful to set out immediately some clarifications, particularly concerning the dialectic relationships between the Constitutional Court and other national judges.

At the beginning of its republican age, Italy opted for a Kelsenian model of judicial review with a peculiar feature: the competence to declare a law unconstitutional and void was concentrated in a specially designed tribunal (the Italian Constitutional Court); but every court was vested with the duty and power to

\footnotetext{
${ }^{16}$ N. Luhmann, Rechtssoziologie [A Sociological Theory of Law] (Taschenbuch 1972); M.R. Ferrarese, 'Recensione al volume La Corte nel contesto di Diletta Tega' [Review of the book 'The Court in Context' by Diletta Tega], 71 Rivista Trimestrale di diritto pubblico (2021) p. 424.
} 
appraise the constitutionality of any law to be applied in a case, and to question its validity before the Constitutional Court, in incidental proceedings, whenever the relevant doubts were not deemed manifestly ill-founded; direct recourse to the Constitutional Court was not - and is still not - available to the citizens.

At first, ordinary judges were quite reluctant to challenge laws by referring constitutional questions to the Court, as the culture of constitutional justice was still unfamiliar. This changed gradually - particularly from the second half of the 1960 s - as incidental proceedings became more and more frequent. Over time - most notably in the 1990s - ordinary courts became so confident in their role of judicial review, that, within the system of constitutional justice, the balance between centralised and diffuse elements started to tilt, to the detriment of the Constitutional Court.

Two developments can be considered exemplars of this trend. First, the Court itself encouraged ordinary courts to make use of their own interpretative powers whenever a question of constitutionality could be resolved through an interpretation that is consistent with the Constitution (interpretazione conforme). As a general rule, the Court would declare inadmissible a question, if the referral order failed to explain that such a remedial interpretation was impossible (e.g. see judgment no. 356/1996). This doctrine was developed to reduce the considerable number of questions that were being referred to the Court for a decision. However, over the long term it jeopardised the incidental method of access: many constitutional problems were no longer referred to the Italian Constitutional Court, but resolved by the ordinary courts directly, under their own initiative, by interpreting laws in line with the Constitution.

Second, the Court, emphasising the Constitution's openness to international and supranational integration, highlighted the expansion of the role of other bodies charged with guaranteeing rights, such as the European Court of Human Rights (whose judgments work as constitutionally binding clarifications of Italian obligations under the ECHR) and the European Court of Justice - the latter in cooperation with ordinary national courts, empowered also to set aside domestic legislation under the Simmenthal doctrine, possibly after referring preliminary questions (not to the Constitutional Court, but) to the Luxembourg Court. Consequently, the Italian Constitutional Court witnessed an increasingly widespread vesting of authority to provide legal protection for rights in courts with different characteristics to its own, including in particular a reduced (or even non-existent) systemic perspective. ${ }^{17}$

This background helps in understanding the Italian Constitutional Court's strategies of re-centralisation. On the one hand, from 2015 onwards (judgment no. 221) the Court softened its position on interpretazione conforme: judges are no

\footnotetext{
${ }^{17}$ See D. Tega, I diritti in crisi [Rights in crisis] (Giuffrè 2012).
} 
longer requested to raise only questions which are demonstrably impossible to solve through consistent interpretation; now it is sufficient to explain that such a construction faces relevant obstacles; ultimately, just entirely inadequate attempts at consistent interpretation are sanctioned by rulings of inadmissibility. This exemplifies a first, broader sense of re-centralisation: the Italian Constitutional Court re-acquires occasions for adjudication on the merits of constitutional questions, which previously had been left to other judicial bodies (ordinary courts).

On the other hand, a second meaning of re-centralisation becomes apparent: through adjustments to its procedural case law, the Constitutional Court reinforces and reclaims spaces of jurisdiction which were previously caught in centrifugal dynamics. Most notably, under this second perspective, this article will focus on the decisions of the Italian Constitutional Court that have redefined some of the core aspects of the relationship between it, the European Court of Justice and ordinary courts acting for the enforcement of EU law.

Before turning to this issue, it is worth noting that the general tendency of the current era - towards a stronger, more active and central role of the Italian Constitutional Court - is also apparent within several other lines of decisions. For example, it is important to recall the decisions that remodelled: the substantive content of national electoral law (no. $1 / 2014$, confirmed by no. $35 / 2017^{18}$ ); the maximum and minimum limits stipulated for criminal offences (no. 40/ 2019); and the temporal effect of decisions ruling legislation unconstitutional (no. $10 / 2015^{19}$ ), despite the lack of any provision regulating such aspects within Italian legislation on constitutional justice. This is not to mention the two rulings on assisted suicide (nos. 207/2018 $8^{20}$ and 242/2019), which first directed Parliament to draft legislation and subsequently, following the absence of a response, recognised the right to die with dignity for persons in full command of their mental faculties who are affected by irreversible disease that causes intolerable physical and psychological suffering. These are all examples of cases in which the Italian Constitutional Court has been proactive in manipulating the applicable law in order to dispense constitutional justice, notwithstanding the discretion vested in the legislature. Nevertheless, in all cases the Court has clarified that the legislature is always free to make provision even after the constitutionality proceedings, for instance in order to recalibrate the sanctions framework.

\footnotetext{
${ }^{18}$ Already discussed in detail by P. Faraguna, 'Do You Ever Have One of Those Days When Everything Seems Unconstitutional?: The Italian Constitutional Court Strikes Down the Electoral Law Once Again', 13EuConst (2017) p. 778.

${ }^{19}$ Addressed by C. Bergonzini, 'The Italian Constitutional Court and Balancing the Budget', 12 EuConst (2016) p. 177.

${ }^{20} \mathrm{~F}$. Viganò, 'The Italian Constitutional Court on assisted suicide, 27 November 2018, available at 〈www.criminaljusticenetwork.eu/en/home〉, visited 12 August 2021.
} 
However, as a matter of fact in many cases the legislature has decided not to become involved and the balance between the various interests in play has remained that set by the Court.

It is not appropriate to dwell further on specific examples concerning issues different from that on which this article is focused. Returning to a broader perspective, the capacity of the main changes within the case law during the era of re-centralisation to reshape the boundaries to constitutional review, in particular vis-à-vis political discretion, has been considered as yet another example of judicial activism, and it has been asserted that the re-centralisation case law has disrupted the equilibrium between branches of state. However, this type of criticism is nothing new, and has been raised throughout the Court's history. For example, as early as 1981, Franco Modugno, now a justice on the Constitutional Court, spoke of the encroachments ${ }^{21}$ that were jeopardising the viability of the separation of powers itself, in turn citing Vezio Crisafulli from the 1958 publication Corte costituzionale e potere legislativo [The Constitutional Court and the Legislature]. ${ }^{22}$

Indeed, in this debate, two lines of thought confront each other, while at the same time echoing classical issues of constitutional justice. On the one hand, it is argued that judicial elites, through their activism, pursue a deliberate strategy of replacing political decision makers gripped by paralysis (due to the weakening of political parties or movements and the fragile nature of coalition governments). On the other hand, attention is brought to the counter-majoritarian nature of courts, whose typical task is counteracting majoritarian views where they risk becoming tyrannical. This last function, coupled with the resulting difficulties, has been invoked as justification for the more creative decisions in the area of the criminal law, under which the classical doctrine of 'set rhymes'

\footnotetext{
${ }^{21}$ This notion, significantly, recalls the title of one of the most interesting critical studies of the Bundesverfassungsgericht, C. Schönberger et al., Das entgrenzte Gericht (Suhrkamp 2011), edited and translated by T.L. Putman, The Court without Borders (Oxford University Press 2016), which has also been used recently in a critical sense by A. Morrone, 'Suprematismo giudiziario. Su sconfinamenti e legittimazione politica della Corte costituzionale' [Judicial supremacism. On encroachments by and the political legitimation of the Constitutional Court], 39 Quaderni costituzionali (2019) p. 251.

${ }^{22} \mathrm{~F}$. Modugno, Corte costituzionale e potere legislativo [The Constitutional Court and the Legislature], in P. Barile et al. (eds.), Corte costituzionale e sviluppo della forma di governo in Italia [The Constitutional Court and development of the system of Government in Italy] (il Mulino1982) p. 19 at p. 47; V. Crisafulli, 'La Corte costituzionale tra magistratura e parlamento'[The Constitutional Court between the judiciary and Parliament], in Scritti giuridici in memoria di P. Calamandrei, IV, [Legal writings in memory of P. Calamandrei] (Cedam 1958), the Court's review of legislation alters the traditional configuration of the separation of powers and 'more specifically impinges upon the framework of parliamentary government, considered in its broadest sense as that system of government in which Parliament lies at the centre of power', p. 277.
} 
(rime obbligate) ${ }^{23}$ has been set aside in favour of others that, in the same vein, might be defined as 'free solutions'. Under the classical doctrine, when a criminal provision was found to be unconstitutional but there was no single, constitutionally-mandated solution (a 'set rhyme') for remedying the unconstitutionality, the Italian Constitutional Court usually refrained from striking down the provision, in order to leave the choice among the relevant options to the legislator. ${ }^{24}$ Since 2016, the Court has relinquished this traditional deference towards the legislature in criminal matters, mostly due to the latter's inability to take action and in the name of the protection of personal freedom. While reiterating that discretionary decisions concerning the severity of punishments fall, above all, to the legislature, the Italian Constitutional Court has explained that it now feels empowered to take action against manifestly unreasonable or arbitrary legislative choices in relation to punishments, provided that one condition is met: the solution for re-establishing consistency with the system of criminal law, where it protects a certain legal interest, must be found within the system itself. Thus, if the system provides more than one viable option (i.e. if there is more than one provision that could arguably replace the invalid one), the choice (among several 'free verses', although such a choice is never entirely free and unfettered by law) can be made by the Italian Constitutional Court itself in order to proceed in a timely manner, whenever possible, to eliminate unjustifiable inconsistencies' (judgments nos. 236 of 2016, 233 of 2018, 40 of 2019).

I am not seeking here to negate either the counter-majoritarian dynamic or aspects of judicial activism: indeed, the weakness, disorientation and aimlessness of the political class are undoubtedly amongst the causes of the current era together with other broader causes. However, I argue that these aspects are not sufficient to explain all of the reasons underlying a body of case law that cyclically generates new decision-making templates and modules and sets aside previous procedural rules: changes in case law should not always be branded as sudden and arbitrary new departures from consolidated positions as they may be traced back to the search for legitimation within the context in which the Court operates at different points in time.

\footnotetext{
${ }^{23}$ English translations on the website of the Court use the rather less poetic 'mandatory solutions'.

${ }^{24}$ See W.J. Nardini, 'Passive Activism and the Limits of Judicial Self- Restraint: Lessons for America from the Italian Constitutional Court', 30 Seton Hall Law Review (1999-2000) p. 1. The author translates 'rime obbligate' as 'prescribed verses'.
} 


\section{Constitutional JUSTICE AND ITS CONTEXT}

Häberle set out four factors that are liable to condition the work of bodies charged with interpreting the Constitution: (i) legislative instruments, executive ordinances and judicial rulings, along with the definitively binding decisions of the Federal Constitutional Court; (ii) the overall body of opinions and statements submitted by the parties, expressed on various levels and in different forms, including committees of inquiry as well as legislative and executive hearings; (iii) political parties, federations and associations, churches, committees and initiatives pursued by citizens and the mass media; and (iv) constitutional law doctrine as a science and culture, including in particular publications written in conjunction with state bodies, publications and studies dedicated to scientific or cultural matters within the remainder of the public sphere and the works of constitutional scholars from elsewhere in Europe and from other countries (judicial comparison) as precursors to a European constitutional doctrine. ${ }^{25}$

Amongst these four factors, in Italy it has without doubt been the social, institutional and normative context that has had the most far-reaching effect on the role of the Court.

In particular, the overall context in Italy results from the type of applications submitted to the Court by a society that is becoming increasingly dissatisfied with the responses offered by political authorities and is directing its action towards guarantee bodies (through the incidental method of access, as there is no direct individual access), asking them to take action in order to protect, for instance, civil liberties and social freedoms, the family, employment and litigation rights, acting either temporarily or even in some cases permanently in place of the legislature. ${ }^{26}$ Courts, in general, do not operate in isolation from the society for which they determine what the law is. ${ }^{27}$

The context is also provided by the Court's relations with other guarantee bodies (in particular the President of the Republic) and with governmental bodies, in the light of their respective modes of functioning (or of not functioning...).

Even the assertion of supranational legal paradigms that claim constitutional status, thereby eroding national constitutionalism, has an effect on the context. ${ }^{28}$

${ }^{25} \mathrm{P}$. Häberle, Verfassungslehre als Kulturwissenschaft [Constitutional theory as cultural science] (Duncker \& Humblot 1982).

${ }^{26}$ See E. Lamarque, Corte costituzionale e giudici dell'Italia repubblicana [The Constitutional Court and Justices of Republican Italy] (Laterza 2012) p. 57.

${ }^{27}$ See D. Grimm, 'What exactly Is Political about Constitutional Adjudication?', in C. Landfried (ed.), How Constitutional Courts Affect Political Transformations (Cambridge University Press 2019) p. 307.

${ }^{28}$ See D. Grimm, 'The achievement of Constitutionalism and its Prospects in a Changed World', in M. Loughlin and P. Dobner (eds.), The Twilight of Constitutionalism? (Oxford University Press 2010) p. 3. 
Thus, for example, the current era of re-centralisation can also be interpreted as a reaction to a context characterised in particular by: legislative inertia and the failure by the legislature to act in response to judgments of the Constitutional Court; ${ }^{29}$ growing normative disorder caused by legislation that is often impulsive and poorly coordinated with the constitutional system; and the drying up of incidental constitutional proceedings mentioned above.

The instruments that the Court uses nowadays to respond to this context have been available since the outset of its history when, first of all, legislative inertia and the difficulty in adapting the normative framework to the new constitutional order were already becoming apparent, and second, more consolidated institutions viewed the Italian Constitutional Court with suspicion as an outsider.

I shall refer to three examples that take us back to the very start of the work of the Italian Constitutional Court in order to explain how the Court was truly effective in appreciating the weaknesses within the surrounding context: it drew strength precisely from the institutional weakness that surrounded it right from the beginning. Despite the troubled, hurried, naïve and at times even unwitting process that led to its establishment, ${ }^{30}$ the early years of the Court's activity show an extraordinary capacity for self-definition. ${ }^{31}$

We should consider first of all the broad scope of the Court's exercise of its regulatory powers (in particular under Law no. 87 of 1953) in order to adopt its own Supplementary Rules (Supplementary Rules on Proceedings before the Constitutional Court, which have been updated several times over the years). In this way, within the space of only a few weeks, the Court was able to directly supplement the Law, which was fragmentary and incomplete, and to set out as it pleased the rules governing proceedings before the Court. The self-assured manner in which the Court has accustomed itself to using constitutional proceedings

\footnotetext{
${ }^{29}$ See R. Bin and C. Bergonzini, 'La Corte costituzionale in Parlamento' [The Constitutional Court in Parliament], in R. Bin et al. (eds.), "Effettività» e "seguito» delle tecniche decisorie della Corte costituzionale ['Efficacy' and 'compliance with' decision making techniques of the Constitutional Court] (Edizioni Scientifiche Italiane 2006) p. 215; N. Lupo, 'Il Parlamento e la Corte costituzionale'[The Parliament and the Constitutional Court], 21 Associazione per gli studi e le ricerche parlamentari, Quaderno (2012) p. 109; F. Musella and L. Rullo, 'The Expansion of the Constitutional Court in Italy: Ruling the Void in Times of Political Instability', 25 Review of Constitutional Studies (2020) p. 79.

${ }^{30} \mathrm{~L}$. Lacchè, 'Il tempo e i tempi della Costituzione' [The time and times of the Constitution], in G. Brunelli and G. Cazzetta (eds.), Dalla Costituzione 'inattuata' alla Costituzione 'inattuale?? Potere costituente e riforme costituzionali nell'Italia repubblicana [From the 'unimplemented' Constitution to the 'out-of-touch' Constitution? Constituent power and constitutional reforms in Republican Italy] (Giuffrè 2013) p. 365.

${ }^{31}$ See F. Biagi, European Constitutional Courts and Transitions to Democracy (Cambridge University Press 2020) p. 41-66; G. Laneve, La giustizia costituzionale nel sistema dei poteri [Constitutional Justice within the Institutional System] (Cacucci 2014) p. 187.
} 
can also be traced back to this point in time. This provided the earliest demonstration of the understanding that the first constitutional justices had of the meaning and characteristics of the functions that the Court was to perform, and their awareness of the innovations that they were introducing.

A second important development in terms of the changing nature of constitutional proceedings came in 1987-1989. During that period, the Court identified and employed novel means for 'disposing of' the large backlog of questions: ${ }^{32}$ most notably, the quick dismissal of many cases on procedural grounds through ordinanze di manifesta inammissibilità (orders declaring manifest inadmissibility), rather than through full-fledged, longer and more demanding sentenze (judgments).

This decision had the effect of focusing the attention of constitutional justices on more contemporary legislation, often that enacted by the current legislature. In doing so, the Court arrived at the boundaries of the political domain. ${ }^{33}$

Third, in substantive terms, the foundational judgment no. 1/1956 (the Italian Marbury v Madison,${ }^{34}$ if you will) provides a further example of the distinguishing capacities of the Court right from the outset, compared to other more traditional institutions under the Italian system (Parliament and the Government). In this first decision, the Court struck down a fascist-era law limiting freedom of expression, which had remained in force for a full eight years after the enactment of the republican Constitution. These proceedings provided the opportunity to make clear to the public at large the innovative scope of this institution, which was ready to uphold and give effect to the fundamental rights proclaimed in the Constitution. The case also offered an auspicious opportunity to assert the breadth and exclusivity of its power of judicial review over legislation. The Court's judicial review also extended to fascist pre-republican legislation. That activity of legislative cleansing was emphatically referred to as the 'great substitution' to stress the fact that the Court was not exercising powers vested in another body, but rather its own powers, in order to perform highly commendable work that others [i.e. Parliament] were avoiding, whether due to inertia or due to opportunist considerations. In making this choice the Court started to establish a relationship of trust with and prestige amongst the general public.

Those years thus saw the emergence, on the one hand, of a not always easy relationship with other institutions, and on the other hand an awareness of the crisis of parliamentary government. Almost ten years later, in 1965,

\footnotetext{
${ }^{32}$ For a number of years, the Court's ordinary business was in fact blocked and its attention was absorbed by an examination of the Lockheed case, which involved the payment of bribes to ministers to favour the acquisition of certain assets to the detriment of competitor companies.

${ }^{33}$ See Grimm, supra n. 27.

${ }^{34}$ Barsotti et al., supra n. 8, p. 30 and p. 34; M. Fioravanti, Costituzione italiana: articolo 2 [Italian Constitution: Article 2] (Carocci 2017) p. 96.
} 
Giuseppe Maranini (a particularly astute, original and critical constitutional scholar) asserted that Italy was experiencing a situation characterised by parliamentary and governmental jealousy towards, and aversion from, all judicial bodies, including the Constitutional Court, in parallel with relatively inefficient parliamentary mechanisms which inherently tended to promote inaction over action. ${ }^{35}$ Those first years of activity brought out a characteristic that would no longer be negated and would be instrumental in shaping the role of the newly created Italian Constitutional Court: its sensitivity to the changed social context, and not only the political context, ${ }^{36}$ operating as a more homogeneous, agile and efficient outsider to a political system that was still in a certain sense disorientated. ${ }^{37}$ It thus came as no surprise, at the end of the 1970 s - when the crisis within political representation, the role of the parties and elected assemblies had come to a head - that the late Carlo Mezzanotte, a brilliant constitutional scholar and constitutional justice, argued that there was not one single issue within political debate on which the Court had not ruled; this was because:

within a political system in which the instruments for choosing between and balancing interests struggle to work properly, coupled with a particularly inarticulate and fragmentary manner of legislating, the tangle of antagonisms widespread throughout the community tends to become denser, and the many contradicting claims that cannot be mediated through politics end up addressing themselves in a disordered fashion towards impartial bodies. ${ }^{38}$

Italian constitutional law thus developed as a judge-made law and an increasingly considerable number of political and institutional choices ended up being made under the aegis of the system of constitutional justice.

To summarise, it is clear from history that constitutional justice was very much left to the Italian Constitutional Court to develop through its own doctrines, which were capable of adapting in line with changes in context. Within a civil law system, the doctrines underpinning constitutional case law are those interpretative constructs, intermediating between positive law and individual cases, that lie at the heart of decisions. As mentioned above, they are influenced not only by the context within which

\footnotetext{
${ }^{35}$ G. Maranini, 'Intervento' [Intervention], in G. Maranini (ed.), La giustizia costituzionale [Constitutional justice] (Vallecchi 1966) p. 353.

${ }^{36} \mathrm{~A}$. Cerri, 'La giurisprudenza costituzionale' [Constitutional case law], 51 Rivista trimestrale di diritto pubblico (2001) p. $1325 \mathrm{ff}$.

${ }^{37}$ A. Simoncini, 'L'avvio della Corte costituzionale e gli strumenti per la definizione del suo ruolo: un problema storico aperto' [The creation of the Constitutional Court and the instruments for defining its role: an open historical problem], 49 Giurisprudenza costituzionale (2004) p. 3065.

${ }^{38} \mathrm{C}$. Mezzanotte, 'La Corte costituzionale: attività e prospettive' [The Constitutional Court: activities and perspectives], in Attualità e attuazione della Costituzione [Current Issues and Implementation of the Constitution] (Laterza 1979) p. 149 at p. 170.
} 
the Court operates, and the role that it performs within this context, but also by the awareness developed by the Constitutional Court over time. These theories are very similar, one might argue, to those developed by the theory of scientific interpretation; however, since they have not been created through scientific interpretation but rather through the application of the law by the courts, they operate in a less dogmatic and systematic fashion, being more pragmatic and at times even empirical. In this regard it is important to recall the words of Paul Freund, a renowned expert in constitutional justice and the American teacher of Antonio La Pergola, 'The Courts are the sub-stations that transform the high-tension charge of the philosophers into the reduced voltage of a serviceable current. ${ }^{39}$ The doctrines elaborated by constitutional courts make up a model for the constant renewal of the body's legitimation within an institutional and social context characterised by change.

\section{Remodelling Granital (Simmenthal)}

The importance of context and the search for legitimation are clearly demonstrated by the re-elaboration and partial rejection, from 2017 onwards, of the doctrine famous in Europe as the Simmenthal case and in Italy as the Granital case. ${ }^{40}$

I think that La Pergola drew specifically on the argument of Paul Freund mentioned above ${ }^{41}$ when he guided the Court towards the adoption of the Granital doctrine (judgment no. 170 of 1984). In this landmark decision the Court held that: Article 11 of the Constitution and Law no. 1203 of 1957 (ratifying the EC Treaty) resulted in a transfer of Italian sovereignty over matters entrusted to the common European organisations under the EC Treaty; therefore, EEC legislation was directly applicable in Italy and overode Italian legislation; ordinary courts were allowed to set aside national legislation directly where it was inconsistent with EU law, without any requirement for incidental review by the Constitutional Court. The Court, however, remains competent to review any violation by EU law of fundamental national constitutional principles and rights. In this decision, after much uncertainty, the Italian Constitutional Court accepted the Simmenthal doctrine.

I am particularly interested here in stressing precisely the context to the Granital decision, and in particular its uncertainties.

${ }^{39}$ P.A. Freund, The Supreme Court of the United States (Meridian Books 1961) p. 114.

${ }^{40}$ See Martinico and Repetto, supra n. 2.

${ }^{41}$ Besides, La Pergola subsequently wrote that the voltage 'professed by the Constitutional Court was later, as it were, transformed into the service current that was necessary in order to make the relationship between the national legal system and the monist Court of Justice work properly by the Court': A. La Pergola, 'Il giudice costituzionale italiano di fronte al primato e all'effetto diretto del diritto comunitario: note su un incontro di studio' [Italian Constitutional Court justices and the primary and direct effect of Community law: notes on a study meeting], 48 Giurisprudenza costituzionale (2003) p. 2419. 
There was first and foremost judicial uncertainty: the monist approach of the Court of Justice (which, in the opinion of La Pergola himself, was acting as if the EEC were a federal state, even though no federal state existed ${ }^{42}$ ) clashed with the traditional dualism which the Italian Constitutional Court had followed until then, and which had led it to claim for itself the task of reviewing any incompatibility between Community law and national law (judgment no. 232 of 1975). ${ }^{43}$ Thanks to the Granital decision, a solution to that contrast was found. Following Freund's teachings, La Pergola constructed a different type of dualism, which mirrored the theory of reciprocal systemic significance, with particular reference to private international law, developed by Santi Romano in The Legal Order (L'ordinamento giuridico, part II). ${ }^{44}$ The two systems remained separate yet coordinated, with predominance being recognised to Community law from the area in which national law had withdrawn in order to leave scope for the Treaty of Rome.

For its part, the national political context certainly did not help, with Parliament indeed expressing outright indifference. This was so far-reaching that it was not possible to achieve an agreement within the Committee for Institutional Reforms, known as the Bozzi Committee (which first sat on 30 November 1983, only a couple of months before the Granital ruling), in order to enshrine the primacy of EEC law within the Constitution. ${ }^{45}$

${ }^{42}$ A. La Pergola, 'L'Unione europea fra il mercato comune ed un moderno tipo di Confederazione. Osservazioni di un costituzionalista' [The European Union: between the common market and a modern type of Confederation. Observations by a constitutional scholar], Rivista trimestrale di diritto e procedura civile (1993) p. $1 \mathrm{ff}$.

${ }^{43}$ Between the end of the $20^{\text {th }}$ and the start of the $21^{\text {st }}$ centuries, a thorough debate was conducted within the literature on how to move beyond the monist/dualist dichotomy, which resulted in the proposed solution of constitutional pluralism: see N. MacCormik, Questioning Sovereignty: Law, State, and Nation in the European Commonwealth (Oxford University Press 1999); N. Walker, 'The Idea of Constitutional Pluralism', 65 Modern Law Review (2002) p. 317; M. Rosenfeld, 'Rethinking constitutional ordering in an era of legal and ideological pluralism', 6 International Journal of Constitutional Law (2008) p. 415; A. von Bogdandy, 'Pluralism, Direct Effect, and the Ultimate Say: on the Relationship Between International and Domestic Constitutional Law', 6 International Journal of Constitutional Law (2008) p. 397.

${ }^{44} \mathrm{~A}$. La Pergola, 'Larticolazione del diritto comunitario e di quello interno' [The structure of Community law and national law], Rivista di diritto europeo (1994) p. 651; C. Pinelli, 'Antonio La Pergola, giurista costruttore' [Antonio La Pergola, a lawyer-builder], XIII Diritto Pubblico (2007) p. 571. See M. Croce (ed. and trans.), The Legal Order (Routledge 2017), the first translation in English of L'ordinamento giuridico.

${ }^{45}$ Barbera, supra n. 14 , p. 352 , recalls that neither Parliament nor constitutional scholars entirely foresaw that the Treaty would have effects also on the system of constitutional law or on the overall legal system. Even today, Italy has not amended Art. 11: 'Italy rejects war as an instrument of aggression against the freedom of other peoples and as a means for the settlement of international disputes. Italy agrees, on conditions of equality with other States, to the limitations of sovereignty that may be necessary to a world order ensuring peace and justice among the Nations. Italy promotes and 
It is particularly important to recall Antonio Tizzano's caustic judgment concerning Parliament and doctrine from that period: legislative and administrative activity were not always consistent and were at times schizophrenic, given the vast contradiction between the constant lip service paid to the European project, as opposed to actual actions that were more lukewarm towards it, if not even outright opposed to it; contrasting demands from doctrinal commentators who were highly committed, but divided, oscillating and extraordinarily effusive, and in some cases even misleading, due to the incredible volume and variety of solutions mooted along with the reasons proposed for them. ${ }^{46}$

Moreover, the Community context was not particularly favourable: the position of the Constitutional Court of one of the six founding members of the EEC was considered to be unsatisfactory and a source of embarrassment.

Thanks to the departure from its traditional doctrine contained in the Granital ruling, the Constitutional Court gained European legitimation, demonstrating to the Community institutions its desire to adapt in line with the approach of the European Court of Justice and to embrace the great Community project. This was, as it were, a type of legitimation that focused on the result.

However, the Italian Constitutional Court did not stop there. Starting with judgment no. 170 of 1984 , it then went on to confirm and expand the Granital doctrine: Community provisions with direct effect are incorporated into Italian law and their efficacy cannot be altered by any national laws, whether enacted previously or subsequently; any incompatible national legislative provisions are disregarded when resolving disputes before the national courts; the non-applicability of the national provision precludes the possibility of seising the Constitutional Court with a question concerning the incompatibility of the national provision with a principle of Community law on the grounds that it violates Article 11 of the Constitution; directly effective Community law is deemed to include not only regulations but also Community law as interpreted within all of the judgments given by the Court of Justice, along with the requirements laid down within Community directives that have been recognised as having direct effect by the ordinary courts or by the Court of Justice.

encourages international organisations furthering such ends', translation available at 〈www. cortecostituzionale.it/documenti/download/pdf/The_Constitution_of_the_Italian_Republic.pdf $\rangle$, visited 12 August 2021.

${ }^{46}$ See A. Tizzano, 'La Corte costituzionale e il diritto comunitario: vent'anni dopo ...' [The Constitutional Court and Community law: twenty years on...], 107 Il Foro italiano (1984) p. 2063; C. Pinelli, Intervento [Intervention], in Atti della giornata in ricordo del Presidente emerito della Corte costituzionale Antonio La Pergola, [Acts of the Commemorative Day for Former President of the Constitutional Court Antonio La Pergola] (Corte costituzionale 2008) p. 43. 
The Italian Constitutional Court has also clarified that, if the ordinary courts are required to resolve both a doubt concerning the interpretation of a provision of Community law that contrasts with a national provision as well as a doubt concerning the constitutionality of that same national provision, a so-called double preliminary question ${ }^{47}$ (doppia pregiudizialità), the Constitutional Court has stipulated a specific procedure: when confronted with an issue of double preliminary questions, precedence must be given to the issue of Community law as it is 'logically and legally prior to the question of constitutionality', since it pertains to the very applicability of the contested provision within the proceedings before the referring court and hence to the relevance of the question. Consequently, a preliminary question concerning constitutionality is inadmissible where the referring court seeks the review of the constitutionality of a provision, whilst at the same time expressing doubt as to the proper interpretation of Community provisions or their potential violation; the question concerning the compatibility of the national provision with Community law must in fact be resolved, with the assistance of the Court of Justice if necessary, before referring a question of constitutionality; if this does not occur, the question of constitutionality will be ruled irrelevant.

Compared to the stance previously followed by the Italian Constitutional Court (e.g., judgment no. 232 of 1975), the change in approach in 1984 showed how the creative potential of constitutional case law could reach new boundaries. However, the change in direction implemented by judgment no. 269 of 2017, at a distance of a number of years, is also significant for this very same reason. This decision sought to move beyond the judicial protocol ${ }^{48}$ established by Granital, reversing the order of priority between EU and constitutional preliminary questions: if it is considered that a national law may potentially violate rights enshrined both in the Italian Constitution and in the Charter of Fundamental Rights of the European Union (in those contexts where EU law applies), the question of constitutionality must be raised, whilst also leaving the possibility of making a referral for a preliminary ruling (concerning issues of interpretation or validity of EU law) under Article 267 TFEU. It is irrelevant whether the provisions of the Charter of Fundamental Rights have or could have direct effect: in any case, the national courts should not set aside the national provisions directly or refer the matter directly and exclusively to the

\footnotetext{
${ }^{47}$ See G. Martinico, 'Multiple loyalties and dual preliminarity: The pains of being a judge in a multilevel legal order', 10(2) International Journal of Constitutional Law (2012) p. 871; Piccirilli, supra n. 1.

${ }^{48}$ See Martinico and Repetto, supra n. 2, p. 734.
} 
European Court of Justice, but must by contrast involve the Italian Constitutional Court by referring a question of constitutionality.

This is what the Court ruled in 2017, clearly influenced also by the increasingly detailed arguments built up over the years by two of its members, Augusto Barbera ${ }^{49}$ and Marta Cartabia, ${ }^{50}$ and considering that the time was ripe to reveal the artificial nature of the Granital doctrine. Many scholars had identified this artificial aspect from the outset, as is now acknowledged following the jurisprudential shift in 2017 also by former President of the Italian Constitutional Court, Gaetano Silvestri:

[much] water has flowed under the bridge since then and perhaps one might venture to say that the contrast between the monist and dualist conceptions was avoided - as far as Italy is concerned - by the Granital judgment through a legal fiction which, useful as it might have been in order to resolve a major difficulty, was destined to betray its true nature sooner or later. ${ }^{51}$

This assertion attracted many responses, including a number of harsh critical comments pointing at an open conflict with EU law and European Court of Justice doctrine, ${ }^{52}$ and the Constitutional Court appears to have intentionally rowed back on it somewhat in other judgments from 2019. ${ }^{33}$ The criticisms voiced in the literature and by the ordinary courts have concerned, in a nutshell, the risk of undermining both the primacy of EU law as well as the role of the ordinary courts as judges of EU law. As regards the latter criticism it appears clear that at least some of the ordinary courts consider themselves to have been stripped

\footnotetext{
${ }^{49}$ A. Barbera, 'La Carta dei diritti: per un dialogo fra la Corte italiana e la Corte di giustizia' [The Charter of Rights: towards a dialogue between the Italian Court and the Court of Justice], 38 Quaderni costituzionali (2018) p. 149.

${ }^{50} \mathrm{M}$. Cartabia, 'Considerazioni sulla posizione del giudice comune di fronte a casi di doppia pregiudizialità comunitaria e costituzionale' [Considerations on the position of the ordinary courts when confronted with issues of double preliminary questions under Community and constitutional law], 120 Il Foro italiano (1997) p. 222.

${ }^{51} \mathrm{See}$ G. Silvestri, 'L'integrazione normativa tra ordinamento italiano ed europeo' [Normative integration between Italian and European law], Nuova Antologia (2020) p. 89. Also, Antonio Tizzano at the time acknowledged that, while the result achieved by judgment no. 170 appeared to be clear, the reason for the change appeared to be less clear, given that the theoretical premises for the revirement had not been changed, see supra n. 46, p. 2072.

${ }^{52} \mathrm{D}$. Gallo, 'Challenging EU constitutional law: The Italian Constitutional Court's new stance on direct effect and the preliminary reference procedure', 25 European Law Journal (2019) p. 434.

${ }^{53}$ In judgments nos. 20, 63, 112 of 2019, the Italian Constitutional Court no longer stated that a question of constitutionality must be raised, but rather chose to assert that the Court's capacity to intervene with erga omnes effect must be preserved.
} 
of a function that they perceive to be essential and have experienced the new doctrine announced by the Court as a means of negating their central role. ${ }^{54}$

As in 1984, this shift has been rooted in a change in context and the quest for legitimation: the Court has not been inspired by considerations of judicial activism or the counter-majoritarian function either in 2017 or in 1984. And it has not even sought to enter into conflict with the European Court of Justice.

The evolution which occurred in 2017 provides a very significant example of the drift towards the re-centralisation of powers by the Constitutional Court. Specifically, there has been a tendency for it to conserve its own central role and functions, including primarily over the judicial review of legislation. The Court claims, first of all, the need for the legal system to be capable of eliminating, with erga omnes effect, any legislation found to be unconstitutional that diffuse review by the ordinary courts, in the name of the primacy of EU law, has only disapplied (and thus not referred to the Italian Constitutional Court). ${ }^{55}$ The Italian Constitutional Court was driven to embrace this change in approach by the institutional responsibility to ensure systemic protection for rights within the Italian legal system.

This systemic protection has been endangered by ordinary courts, whose use of preliminary references (in conjunction with direct effect and non-applicability) threatened to foreclose the space for incidental constitutionality proceedings, as noted above (with regard to the trends which the Constitutional Court sought to resist through its re-centralisation strategy). A wide employment of this practice clearly erodes the very foundations of the constitutional model of rights protection: it derogates from the monopoly of the judicial review of legislation, entrusted to the Constitutional Court, and also allows judges to elude their subjection to law. It is no coincidence that judgment no. 269 of 2017 states that incidental proceedings represent the keystone of the national constitutional order (Article 134 of the Constitution). ${ }^{56}$ Also, the extent of the development experienced by EU law in general, and in particular the issue of fundamental rights, had an impact on the departure from the previous approach in 2017.

The Italian Constitutional Court was not making a simple sovereignty argument, engaging in a Schmittian power play between the EU legal order and the domestic. It

${ }^{54} \mathrm{~A}$. Cosentino, 'Doppia pregiudizialità, ordine delle questioni, disordine delle idee' [Double preliminary questions, order of questions, disorder of ideas], 6 February 2020, available at 〈www.questionegiustizia.it/articolo/doppia-pregiudizialita-ordine-delle-questioni-disordine-delle-idee_ 06-02-2020.php $\rangle$, visited 12 August 2021.

${ }^{55}$ D. Paris, 'Constitutional Courts as Guardians of EU Fundamental Rights? Centralised Judicial Review of Legislation and the Charter of Fundamental Rights of the EU', 11 EuConst (2015) p. 389.

${ }^{56}$ See judgment no. 269/2017, para 5.2. It is interesting to note that the ECJ has classified the preliminary ruling procedure (Art. $267 \mathrm{TFEU}$ ) for some time as the keystone of the EU judicial system: see ECJ 6 March 2018, Case C-284/16, Slowakische Republik (Slovak Republic) v Achmea $B V$, para. 37 and, previously, Opinion 2/13 (Accession of the EU to the ECHR) of 18 December 2014, at para. 176. 
was concerned with the peculiar status of rights when they are enshrined in a Constitution such as that adopted by Italy in 1948. Such an instrument sets out a broad range of rights and principles, envisioning a far-reaching and democratically open project of social and political evolution, which in its turn is reflected in the wide and capillary powers entrusted to the governing bodies of an institutional system with general competence. This is a fundamental difference vis-à-vis legal systems focused on the protection of individual rights only, such as the system based on the ECHR, or, at any rate, on a non-general array of competences, such as EU law. In other words, the same right might well be protected with similar clauses in national, supranational and international charters; but only in the domestic area is it confronted with the full scope of potentially antagonist rights and principles requiring political regulation. The necessity of taking this into account is what the Constitutional court means when it states that the constitutional protection of fundamental rights must be systemic and not piecemeal across a series of uncoordinated provisions (judgment no. 264 of 2012). More specifically, the Court has sought to re-acquire the first say in terms of the guarantee of rights, also in view of the fact that the catalogue of rights contained in the national Constitution cannot be considered to overlap on a conceptual level with those laid down by the Charter. ${ }^{57}$ The Italian Court has claimed the first say both through the channel of incidental review as well as preliminary references to the European Court of Justice. Starting from the preliminary reference (order no. 24/ 2017) made in the case of M.A.S and M.B., only the second in history within incidenter proceedings, ${ }^{58}$ the Italian Constitutional Court started to use that instrument in an increasingly nuanced manner, achieving positive results.

\footnotetext{
${ }^{57}$ M. Cartabia, 'Europe and Rights: Taking Dialogue Seriously', 5 EuConst (2009) p. 5; A. Guazzarotti, 'La sentenza n. 269 del 2017: un «atto interruttivo dell' usucapione» delle attribuzioni della Corte costituzionale?' [Judgment no. 269 of 2017: an 'act interrupting the usucapion' of the powers of the Constitutional Court?], 38 Quaderni costituzionali (2018) p. 194; N. Lupo. 'The Advantage of Having the "First Word" in the Composite European Constitution', 10 Italian Journal of Public Law (2018) p. 186.

${ }^{58}$ The first ever preliminary reference in incidenter proceedings occurred in the Mascolo case, see B. Guastaferro, 'The Unexpectedly Talkative "Dumb Son": the Italian Constitutional Court's Dialogue with the European Court of Justice in Protecting Temporary Workers' Rights in the Public Education Sector', 13 EuConst (2017) p. 493. Lastly, in 2020 (order no. 182) the Italian Constitutional Court referred a question to the ECJ concerning the granting of childbirth and maternity allowances to non-EU citizens. The Constitutional Court had been accessed by the Court of Cassation, questioning the constitutionality of a rule stipulating specific conditions of eligibility for a childbirth allowance and a maternity allowance. First instance and appeal courts that decided on the case found that national provisions were in contrast with an EU directive, which they considered to be applicable and endowed with direct effect, while this was not the opinion of the public administration competent to grant the allowances. The Constitutional Court decided to make a reference for a preliminary ruling to the ECJ, asking whether the relevant norms of the directive were applicable in the cases at hand, and if they were endowed with direct effect.
} 
The positive results have also been confirmed recently. The European Court of Justice judgment of 2 February 2021 (Case C-481/19, DB v Commissione Nazionale per le Società e la Borsa (Consob) $)^{59}$ recognised the right to silence for individuals during investigations relating to conduct punishable by administrative sanctions of a criminal nature. That ruling was obtained thanks to a preliminary reference made by the Italian Constitutional Court (order no. 117 of 2019), which thus facilitated the bottom-up construction throughout the entire European legal space of a new understanding of a fundamental right and common constitutional tradition.

The Italian Constitutional Court heard a referral order from the Supreme Court of Cassation questioning the constitutionality of domestic legislation that did not recognise an accused's right to silence in proceedings that, although formally administrative in nature, entail the imposition of sanctions of a substantially punitive nature. The Supreme Court of Cassation, following judgment no. 269 of 2017, recognised the Italian Constitutional Court's jurisdiction to examine possible conflicts between provisions of national law and the Charter and submit a question of constitutionality. The Italian Constitutional Court was of the view that the legislation could well violate Articles 24(2) and 111(2) of the Constitution, but a finding of unconstitutionality risked creating a conflict with EU law, since the legislation in question stemmed from obligations incumbent on Italy under, initially, Directive 2003/6/EC and, subsequently, Regulation (EU) No. 596/2014. The Court was, however, also of the opinion that the EU secondary law in question was ambiguous, and, under a certain interpretation, could even be incompatible with Articles 47 and 48 of the Charter of Fundamental Rights of the European Union. The Court decided that before ruling on the question of constitutionality, it was necessary to request clarification from the European Court of Justice on the exact interpretation and, possibly, also the very validity of the EU secondary law at issue. To that end, two questions were referred to the European Court of Justice for a preliminary ruling. The first question was whether the EU secondary law at issue must be interpreted as enabling member states not to punish those who refuse to answer questions from a competent authority if that could reveal their liability for wrongdoing punished with administrative sanctions of a punitive nature. In the event of an affirmative answer to that first question, striking down the domestic legislation would not conflict with EU law. In the event of a negative answer to the first question, the second question was whether the provisions of the EU secondary law at issue were compatible with Articles 47 and 48 of the Charter of Fundamental Rights of the European Union

\footnotetext{
${ }^{59}$ D. Sarmiento, 'The Consob Way - Or how the Corte Costituzionale Taught Europe (once again) a Masterclass in Constitutional Dispute Settlement', 54 EU Law Live weekend edition (2021) p. 2.
} 
insofar as those secondary law provisions would require sanctions to be imposed on persons who refuse to answer questions from a competent authority that could reveal their liability for wrongdoing punished with administrative sanctions of a punitive nature.

If this is the result that can be expected from the departure from the Granital doctrine, it really is necessary to revisit the dichotomy between dialogue and conflict that, as mentioned at the start of this article, has been used to characterise some Italian Constitutional Court decisions. Above all the European Court of Justice and the Italian Constitutional Court might be regarded as allies in the task of better configuring rights and common constitutional traditions (Article 6(3) TEU and Article 52(4) of the Charter). ${ }^{60}$ It is clear that, in order to obtain further results of this type, the Constitutional Court will have to persuade the ordinary courts to cede ground to it in cases in which fundamental rights are at stake: the Taricco saga shows how, in particularly complex situations, a preliminary reference from the Constitutional Court may be preferable to one from an ordinary court. ${ }^{61}$ The reasons for this are clear: rights are a core issue within constitutional discourse and the system of constitutional justice. However, it is possible that similar rights codified in different national and supranational instruments may be interpreted differently by different courts, and above all by national constitutional courts and European courts. Under this new form of interpretative interdependence, ${ }^{62}$ the Italian Constitutional Court would like to perform a role that is not marginal and occasional, but rather commensurate with the central function that it performs within the national system of constitutional justice. In order to achieve this goal, the Italian Constitutional Court is not by any means seeking to exclude the

${ }^{60}$ The same has been argued as regards the ECJ and the German Constitutional court: see F. Mayer, 'Judicial Power and European Integration. The Case of Germany', in C. Landfried (ed.), How Constitutional Courts Affect Political Transformations (Cambridge University Press 2019) p. 183.

${ }^{61}$ Piccirilli, supra n. 1. Recently it has been boldly submitted that establishing a reverse preliminary ruling procedure, from the ECJ to national constitutional courts, would enhance the involvement of the latter whenever the national identity of a member state is at stake: see C. Grabenwarter et al., 'The Role of the Constitutional Courts in the European Judicial Network', 27 European Public Law (2021) p. 43.

${ }^{62}$ M. Cartabia, 'Constitutional Courts between Constitutional Law and European Law', speech for the XVIth Congress of the Conference of European Constitutional Courts, Theme: The Cooperation of Constitutional Courts in Europe. Current Situation and Perspectives, 12-14 May 2014, Vienna, available at/www.cortecostituzionale.it/documenti/relazioni_internazionali/ relazioneCartabia.pdf), visited 12 August 2021: 'This constitutional interdependence affects the national constitutional courts' responsibilities: on the one hand they are charged with new duties, because to some extent they are called to serve as European law adjudicators; on the other hand some of their traditional competences are to be adjusted to a more complex legal order. Moreover, the national constitutional courts' mission overlaps in part with the activity of many other judicial bodies and in particular human rights adjudicators, whose decisions impact the work of national Constitutional courts' at p. 1. 
European Court of Justice or to have always and at all costs the 'final say' in controversial cases, but if anything to obtain the right to the 'first say', i.e. to be consulted immediately by the ordinary courts whenever they are confronted with problems touching upon both Italian and European constitutional law. This is a winning strategy: in an age when the right to the 'last say', even on a constitutional level, is often dispersed - or maybe, in some instances, even unattainable - in a complex and sometime fuzzy network of interconnected forums, actors, decisions and dynamics, the starting point can be more important than the ultimate landing point. ${ }^{63}$

\section{Conclusion: CONSTitutional JUSTICE AND itS LEgitimation}

The Italian Constitutional Court has certainly altered the Italian system of government, reinforcing many of the guarantees for individuals and democracy established by the Constituent Assembly. It has had to establish and then maintain, and where possible expand, its own legitimation understood in the Weberian sense of prestige through its exemplary and mandatory status, ${ }^{64}$ which is essential in order to receive cases to rule on (through all available channels, which as mentioned above do not include the possibility of direct application by private individuals, which has proved to be a more fruitful source in other legal systems) as well as to see its decisions in some sense translated into reality (whilst not having any formal instruments to directly oversee their implementation).

Within a context characterised by the crisis in the decision-making capacity of political and legislative bodies, any demonstration by other authorities of their efficiency will enhance their legitimation. Accordingly, although the Constitution has remained unchanged, the weight of the branches of state within the system of government has profoundly affected: the growing loss in the power of policy making branches, i.e. Parliament and Government, has been paralleled by a progressive growth in the weight of guarantor bodies, the Head of State and the Constitutional Court, which are being increasingly incentivised to exercised their powers by the inertia on the part of policy-making branches.

A prominent example of this tendency is the Italian Constitutional Court: it is mindful of the evolution of the political system and ready to join the fray, in the quest for its own popular legitimation, also in order to support the crisis of legitimation that is being experienced by other institutions. ${ }^{65}$ The role of the

${ }^{63}$ Ferrarese, supra n. 16.

${ }^{64}$ M. Weber, Wirtschaft und Gesellschaft [Economy and Society] (Möhr 1922).

${ }^{65} \mathrm{E}$. Bettinelli, 'Corte costituzionale e opinione pubblica (in un sistema politico debole)' [Constitutional Court and public opinion (in a weak political system)], in R. Romboli (ed.), La giustizia costituzionale a una svolta [Constitutional Justice at the Crossroads] (Giappichelli 1991) p. 39. 
Constitutional Court has shifted gradually from that of a guarantor of the values enshrined in the original constitutional compact to a body for protecting fundamental rights and reviewing the reasonableness of the balances struck between them, as asserted on all levels, whether national or European. The Court is increasingly viewing the guarantee of those rights as the basis for its own legitimation and that of its judgments. One might certainly be struck by the extremely self-assured manner in which the Italian Constitutional Court has handled procedural instruments since 1956, continuously reaching beyond the limits previously set for itself, constantly expanding its powers to intervene in areas characterised by discretion, and proposing alternative legislative solutions.

In particular, the Italian Constitutional Court has developed four types of and channels for legitimation, which I think might be clearer now, in the light of the albeit brief examples and references provided above to constitutional case law throughout history.

The first form of legitimation is the ex ante legitimation rooted in the Constitution and the need to defend it (the Constitution as a limit on power): the Court is legitimised by the fact that it is provided for directly under the Constitution, and due in particular to the Constituent Assembly's choice in favour of a rigid constitution superior to other sources of law.

The second is an ex post form of legitimation which is derived from its wisdom: ${ }^{66}$ from how it exercises its powers, from the equilibrium between the various interests that it is able to establish, from the reasons given for its decisions, and from the respect for the limits that the Court itself encounters (including the limit of self-restraint).

The third is the legitimation that is constructed through direct engagement with public opinion as well as social consent. ${ }^{67}$

The fourth is the legitimation that has developed within relations with other guarantee bodies. This is particularly significant in Italy with regard to the other great guarantor of the constitutional system, the President of the Republic: in a number of cases the two institutions have supported each other in order to resolve and mitigate problems created by political bodies. One particularly prominent example is judgment no. 22 of 2012. That decision forcefully asserts the principle that, when Parliament converts a governmental decree-law into law, it must respect the coherence and homogeneity of the original decree. The decision sought to condemn the practice (frequently applied by Parliament and

\footnotetext{
${ }^{66}$ See Q. Camerlengo, 'La saggezza della Corte' [The wisdom of the Court], 61 Rivista trimestrale di diritto pubblico (2011) p. 647.

${ }^{67}$ In more recent years, the Italian Constitutional Court has enhanced public announcements concerning its decisions and functions by upgrading its website and social media channels, organising series of meetings in schools and prisons and engaging with intellectuals.
} 
governments) of exploiting the opportunity offered by the legislative conversion procedure for incorporating provisions into decrees that are entirely new and have nothing to do with its original content, simply using it as a kind of legislative fasttrack. The decision expressly notes that for some time Presidents of the Republic have been inviting Parliament within official messages to refrain from this aberrant practice, and transforms this invitation, which had not been acted upon, into a judicial precedent which it will be very difficult to avoid.

Considering channels of legitimation and how they operate in each context, and in particular in the present one, helps to understand better the current era of re-centralisation, and above all the stance of the Italian Constitutional Court towards the European Court of Justice.

In the same way as the openness to consistent interpretation, the broad openness of to the Simmenthal doctrine ended up calling into question some of the channels for legitimation: in particular, it appeared that the effect of the Nice Charter, as conveyed through interaction between the ordinary courts and the European Court of Justice, might supplant the function vested in the national constitutional justice system. Similarly, it appeared that the task of striking the balances called for by economic and social life - whenever the legislature proved to be inadequate to such an endeavour - were also tending to drift increasingly towards the area of European justice. Thus, in order to contain these dynamics and to maintain some important channels for legitimation, the Italian Constitutional Court chose to become involved not by excluding the Court of Justice but rather by opening up a new channel for communication that has made the Constitutional Court - which is no longer a reluctant player ${ }^{68}$ as in the past an important interlocutor with the Court of Justice, establishing a necessarily dialectical relationship with it under which the Italian Constitutional Court claims the 'first say'. Ultimately, this may have the potential to enhance the legitimation of both courts.

${ }^{68}$ Cartabia, supra n. 62. 